\title{
THE GERMICIDAL EFFECT OF LACTIC ACID IN MILK *
}

P. G. HEINEMAN N

(From the Department of Hygiene and Bacteriology, University of Chicago)

Reference to the germicidal effect of sour milk or buttermilk on pathogenic bacteria is occasionally found in the literature. It has been intimated that lactic-acid-producing bacteria are a protection against infectiousness of contaminated milk, inasmuch as the acid produced by these bacteria is said to destroy pathogenic bacteria. There is however little positive evidence to show whether this assumption is true or not. Earlier work by Barthel, ${ }^{1}$ Bassenge, ${ }^{2}$ and Behla ${ }^{3}$ is contradictory. An investigation by Northrup 4 as to the fate of typhoid bacilli in milk and in lactose broth, acidified by cultivation of lactic acid bacteria and filtered through a Chamberland filter, seems to show that acid produced by different lactic acid organisms varies in degree of germicidal action. While one strain of "Bacterium lactis acidi" destroyed typhoid bacilli when 0.33 percent acid (as lactic acid) was present, other strains, including the bacillus bulgaricus, had the same effect only when nearly twice as much acid was present. Krumwiede and Noble ${ }^{5}$ determined the longevity of typhoid bacilli in sour cream. The authors make the following deductions from their work:

The typhoid bacillus is gradually killed in sour cream by the acids produced, the rate of destruction being proportionate to the degree of acidity and the number of typhoid bacilli present. The apparent disappearance of typhoid bacilli in sour cream, where the normal flora is present, is due in part to overgrowth of the typhoid bacillus by these bacteria and the difficulty of finding by our present methods the proportionately few typhoid bacilli remaining.

With a moderate contamination, the typhoid bacilli were killed in about four days. With a heavy contamination, or where initial multiplication has taken place, a longer time may be required. For this reason a clean cream which soured slowly would be more dangerous if contaminated, as an initial multiplication of the typhoid bacilli would occur and a longer time would be required to destroy the bacilli. Whether under ordinary conditions the overgrowth by the bacteria of the cream is a factor in the death of the typhoid bacilli cannot be determined by our present methods.

* Received for publication April 8, 1915.

1. Die Bakteriologie des Meiereiwesens, Leipsig, 1901.

2. Deutsch. med. Wchnschr., 1903, 29, p. 675.

3. Lafar: Handbuch d. Tech, Mykologie.

4. Michigan Agr. Exper, Sta., Technical Buull., 1911, 9.

5. Am. Jour. of Public Fealth, 1914, 4, p. 1006. 
There are several factors which render this problem difficult of approach. It is known that germicidal agents act differently on bacteria according to the medium in which the action is studied. Not only the substances composing the medium, but the concentration of the substances in the medium, is of importance. We should expect that a certain amount of a germicide in broth, for instance, would act differently on bacteria from the same amount in milk. Milk, therefore, is the only suitable medium for experiments bearing on our subject. But in the use of milk difficulties again are encountered. The growth of saprophytic bacteria in this medium is so prolific that before the lapse of many hours we have to deal with large numbers. Pathogenic bacteria, even if present in numbers large enough to be infectious, might be overlooked by the plating method-the only method available in the present state of bacteriologic technic. We have to consider also that the kinds of acid produced during the natural process of the souring of milk are not always the same. Lactic acid is generally predominant, but other acids of different germicidal value are often formed in larger or smaller quantity. At relatively high temperature, the bacilli of the bacillus coli group are more active than at low temperature so that larger amounts of volatile acids are produced. Other products of bacteria may influence the results one way or the other. Finally, milk contains a large amount of organic compounds which absorb some of the acid formed and, consequently, cause the germicidal effect to be diminished. The so-called incubation period of milk is due in part to absorption by the casein of acid formed by bacteria.

Another difficulty not to be overlooked is the variable resistance of bacteria to germicidal agents. When a culture of typhoid bacilli comes in contact with a germicide which destroys the majority of cells but leaves an appreciable number of more highly resistant individuals, these multiply and leave the milk in a dangerous condition even tho not present in sufficient numbers to permit detection with certainty. The variability of bacteria in their resistance to inimical conditions is well illustrated by the work of Ayers and Johnson, ${ }^{6}$ who found that some cells of Streptococcus lacticus and of Bacillus coli may survive pasteurization.

In consideration of these difficulties it seemed to me important to test the effect of sterilized mixtures of milk and lactic acid on pathogenic bacteria. It is true that by doing this some of the factors which

6. Jour. Agr. Research, 1914, 2, p. 321; 1915, 3, p. 401. 
may be important are excluded. The influence of saprophytic bacteria and the influence of acid other than lactic acid are not brought into play. On the other hand, this method has the advantage of dealing with pure cultures so that all but a small number of the bacteria can be detected. It was found not practicable to count colonies in plates prepared from undiluted milk, as much precipitated casein was present which obscured colonies.

A series of experiments was carried out under the following conditions. Into each of eight 500 c.c. Erlenmeyer flasks were placed 300 c.c. certified milk from which about 90 percent of the cream had been removed. To these flasks pure lactic acid was added successively in the following amounts: $0.4 \mathrm{c} . \mathrm{c} .=$ 0.13 percent, 0.8 c.c. $=0.27$ percent, 1.2 c.c. $=0.40$ per cent, 1.6 c.c. $=0.53$ percent, 2.0 c.c. $=0.67$ percent, 2.3 c.c. $=0.77$ percent, 2.6 c.c. $=0.87$ percent, and 2.9 c.c. $=0.97$ percent The flasks were then sterilized in an autoclave for fifteen minutes under fifteen pounds pressure.

These quantities of lactic acid were determined after a number of preliminary experiments. Since part of the lactic acid combines with the calcium of the casein, it is necessary to titrate the mixture of milk and acid after sterilization to determine the exact amount of active acid. It was apparent that in different lots of milk the amount of acid thus "lost" was not always the same. Titrations, therefore, had to be made with every fresh lot of milk. After titration six flasks were selected out of the eight so that as nearly as possible each flask contained a fairly regular amount of acid in excess of the previous flask. Titration was carried on with $0.05 \mathrm{n} . \mathrm{NaOH}$ with phenolphthalein as indicator. The smallest amount of acid was approximately that of raw milk. . Some of the acid in raw milk is lost by heating so that the smallest amount of lactic acid added restored approximately the normal amount present in raw milk. Evcn this small amount caused precipitation of some of the casein during sterilization, as some of the acid must have combined with the calcitum of the casein. The amount of acid in the succeeding flasks was increasingly larger, until the last flask contained about as much acid as is usually found in palatable buttermilk.

After the amount of acid was determined by titration, the flasks were inoculated with cultures of the bacteria to be tested. Plates were prepared after inoculation to determine the number of bacteria per c.c. The medium used for plating was beef extract agar of 1 percent acidity, except for Bacillus diphtheriae. In this case, 1 percent hörse serum was added to the medium. The flasks were then incubated at $37 \mathrm{C}$. For three successive days the milk in each flask was titrated and plates prepared. It scemed sufficient to continue plating for three days, since buttermilk of greater age is rarely consumed. The plates were incubated for two days at $37 \mathrm{C}$. and then the colonies counted. The following bacteria were tested: B. coli, B. dysenteriae (Flexner), B. typhosus, B. diphtheriae (Park 8), B. paratyphosus B, Spirillum cholera. Cultures were prepared in broth and the same volume of the culture added to each flask. To each flask was added 1 c.c. of the culture of B. coli, 2 c.c. of the culture of $\mathrm{S}$. cholerae, and 1.5 c.c. of each of the other four cultures. These volumes were decided upon after preliminary experiments so as to control to some extent the numbers inoculated.

The temperature for incubating the flasks was $37 \mathrm{C}$. This of course is higher than the temperature at which buttermilk is prepared. The multiplication of 
pathogenic bacteria at $37 \mathrm{C}$. would naturally be greater than at the lower temperature at which buttermilk is made. This perhaps makes the experiments vary in a measure from natural conditions, but on the other hand germicides usually have greater effect at higher temperatures and possibly the difference is not great.

In Table 1, all the data are given.

Bacillus Coli.-In Flask 1, the initial acidity of 0.14 percent increased to 0.45 percent in two days and the number of bacteria increased from $1,610,000$ to $410,000,000$. On the third day the acidity was 0.53 percent. The number of bacteria had decreased slightly. Flasks 2 and 3 , in the ratio of increase of acid and the number of bacteria, were similar to Flask 1. In Flask 4, the initial acidity was 0.52 percent, which after twenty-four hours had not increased. The number of bacilli after twenty-four hours had decreased materially, and after two and three days no bacilli could be found in a dilution of 1:10. In Flask 5, the result was similar to that of Flask 4, perhaps slightly more pronounced. In Flask 6, with 0.67 percent acidity, all bacteria were destroyed within twentyfour hours. The remarkable thing about this series is the fact that when the acidity was low at the time of inoculation, as in Flasks 1 and 2, the numbers were still high when 0.53-0.55 percent acid was present on the third day. But when the initial acidity was 0.52 percent or more, very few bacteria survived. The probable explanation is that among the cells inoculated there were some that were able to resist and multiply in greater acidity than other cells. These resistant cells became more tolerant to the acid as it developed, through their own metabolism, and we finally have as a result of multiplication a large number of highly resistant bacilli. If, however, inoculation took place in a flask with relatively high initial acidity, the cells of higher resistance had no chance to become accustomed to greater acidity and practically all died in relatively short time.

The limits of acid tolerance of Bacillus coli seem to be about 0.58-0.60 percent acid.

Bacillus Dysenteriae.-In Flask 1, there was considerable multiplication of bacilli within twenty-four hours at an acidity of 0.20 per cent. On the second day at 0.30 percent acidity, the number was practically the same; but on the third day there was a decided decrease. The limits of acid tolerance seem to be between 0.3 and 0.4 percent acid. In Flask 2 , there was a rise in the number of bacteria and an increase of acid to 0.29 percent within two days. After this there was a decrease in bacterial numbers and a slight increase in acid. There is evidently a distinct relation between bacterial numbers and amount of acid when dealing with pure cultures. In the other four flasks, no bacteria were found after twenty-four hours. The initial acidity in these flasks was above the limits of tolerance. In Flasks 3 to 6 , the initial number of bacteria was much smaller than in Flasks 1 and 2, altho the same volume of the same culture was added. It seems probable that the initial amount of acid was so great that a large number of bacilli were destroyed during the time elapsing between inoculation and plating, altho this was done with the utmost expedition. The initial number of bacteria became less as the amount of acid became greater in successive flasks.

Bacillus Typhosus.-In Flask 1, there was an increase after twenty-four hours and a decrease after two and three days. The increase of acidity from the second to the third day was slight, but reduction of the numbers of bacteria was considerable. Reduction of numbers commenced at 0.3 percent acid. In Flask 2, the highest amount of acid was reached on the third day. This 


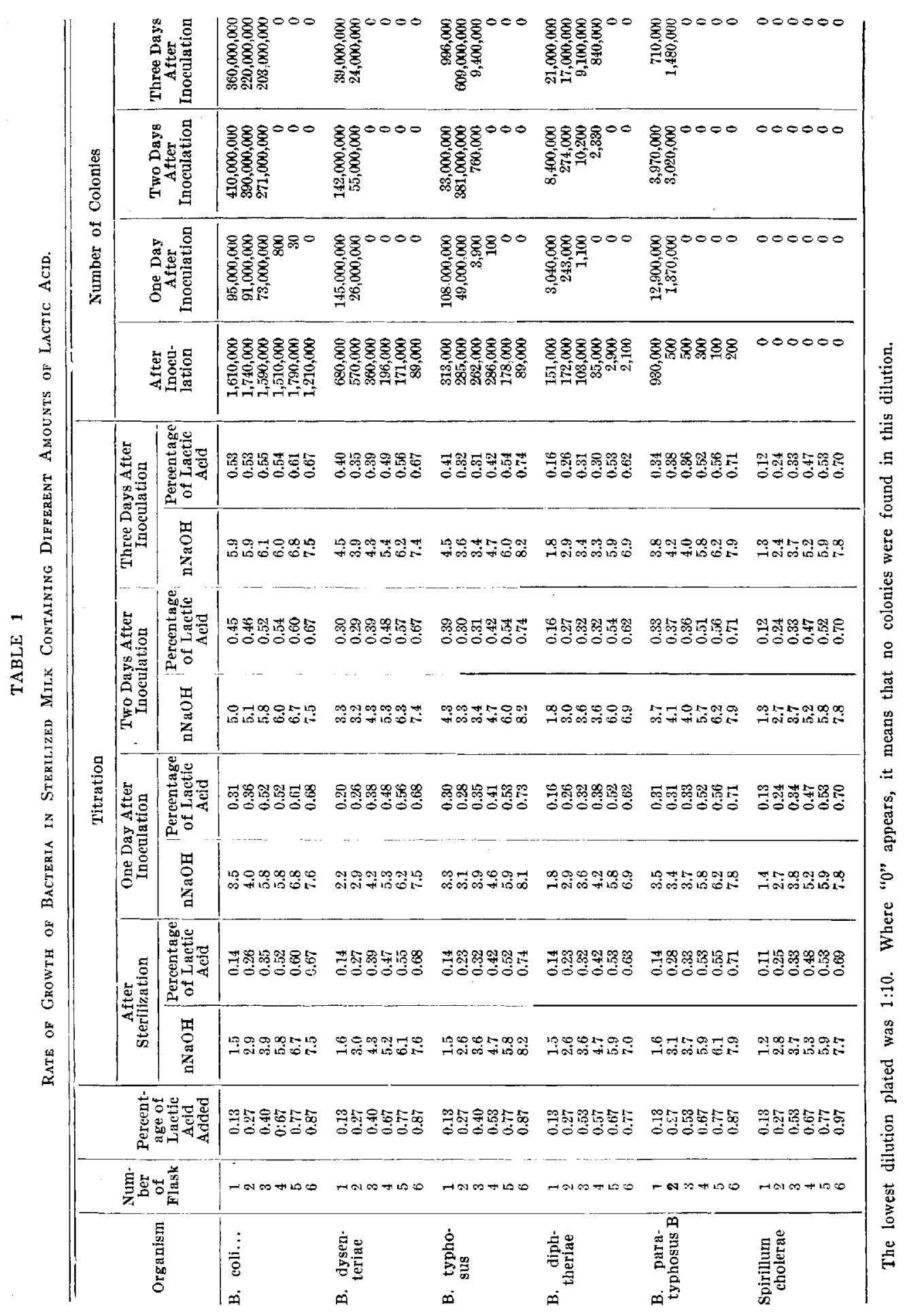

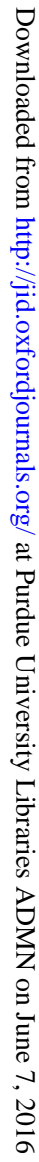


amount, however, was but slightly higher than in Flask 1 after twenty-four hours. This may be explained by the survival and multiplication of acid tolerant forms, and it is worthy of notice that in Flask 2 the numbers increased to the end, reaching the large number of $609,000,000$. Here again is evidence of a relation between bacterial numbers and the amount of acid. In Flask 3, we find a decrease after twenty-four hours with a slight increase in acidity. On the second and third days there was considerable increase. This can be explained by the destruction of the majority of cells under the influence of the initial amount of acid, leaving some cells of high acid tolerance. These multiplied in spite of the acid for some time. The amount of acid decreased somewhat on the second and third days, possibly due to the ability of this strain of typhoid bacilli to produce alkali in milk. In the fourth flask, nearly all bacilli were destroyed within twenty-four hours and none could be found after that. In Flasks 5 and 6 , all bacilli were destroyed during the interval between inoculation and plating. The limits of acid tolerance of Bacillus typhosus lie between 0.3 and 0.4 percent acid.

Bacillus Diphtheriae.-In Flask 1, there was a steady increase in numbers of bacilli with a slight increase in acidity. In Flask 2, the increase in numbers was relatively small, as was also the increase in acidity. In Flask 3 , we have at first a reduction in numbers and then a decided, tho relatively small, increase. The amount of acid remained unchanged. In Flask 4, no colonies were found after twenty-four hours in a dilution of $1: 10$. A few colonies, however, must have survived, since there were 2,330 after two days and over $9,000,000$ after three days. The amount of acid was reduced from 0.42 to 0.30 percent. The strain of Bacillus diphtheriae (Park 8) which was used in these experiments is the same strain that is used widely for preparation of diphtheria toxin. During the incubation period of the toxin there is at first a formation of acid, followed by formation of alkali. Possibly this same process took place in the milk and the fact explains the decrease in acid. In Flask 5, one colony was found after twenty-four hours in a dilution of $1: 10$ and in Flask 6, none was found. There was considerable reduction of numbers of bacteria in Flasks 4, 5, and 6 during the interval between inoculation and plating. The limits of acid tolerance of Bacillus diphtheriae are between 0.27 and 0.32 percent acid.

Bacillus Paratyphosus B.-In Flask 1, there was an increase after twenty-four hours, followed by a decrease after two and three days. The acidity increased from 0.14 to 0.34 percent. In Flask 2 , there was an increase after one day, but large numbers were destroyed immediately after inoculation. Some highly resistant cells must have survived, since after two days $3,000,000$ were present. In Flasks 3 to 6 , there were no colonies found after twenty-four hours. The reduction immediately after inoculation was decided in Flasks 2 to 6 . This series was the second one, the results having been rather unexpected so that repetition seemed advisable. The limits of acid tolerance of Bacillus paratyphosus $B$ are between 0.28 and 0.37 percent acid.

Spirillum Cholerae.-This organism is known to be sensitive to acids. In two successive series no colonies could be found either immediately after inoct1lation, or after one, two, and three days.

Under the conditions of the experiments reported, it would be hardly safe to assume that Bacillus coli is always destroyed in the presence of 0.6 percent lactic acid in milk. It is true that but few survived in the experiments, but the amount of acid which did not abso- 
lutely destroy all bacilli in twenty-four hours was 0.6 percent. For Bacillus dysenteriae the amount of acid necessary to destroy all bacilli with certainty was above 0.4 percent, probably close to 0.42 percent. Bacillus typhosus seemed to be destroyed at about 0.42 percent, altho there was great reduction of numbers at 0.35 percent, or perhaps even below this figure. Bacillus diphtheriae was found alive in 0.32 percent acid, but not in 0.42 percent after twenty-four hours. Bacillus paratyphosus $B$ seemed to be destroyed by 0.33 percent acid.

It seems safe to assume that all bacteria tested in these experiments are destroyed when the acidity of milk reaches 0.45 percent, except Bacillus coli. Since this organism is present in practically all market milk, its presence in buttermilk would not indicate danger. Buttermilk usually contains $0.6-0.9$ percent acid. It might seem that with this amount of acid, buttermilk could be considered safe, even tho the original milk had been contaminated with pathogenic bacteria. The experiments, however, show that there is a possibility of strains of exceptional acid tolerance multiplying. Whether such strains are able to multiply in amounts of acid higher than those occurring in these experiments remains an open question. If the initial pollution is heavy, such a possibility exists and therefore too much reliance should not be placed on the safety of buttermilk unless prepared from pasteurized milk. The experiments indicate however that danger of infection from buttermilk is much smaller than from sweet raw milk.

The experiments were made with pure lactic acid at the outset. This condition was somewhat modified by acid produced by the metabolism of some of the bacteria, chiefly by Bacillus coli, and to some extent by the other test organisms except Spirillum cholerae. The amount of acid present, after incubation in those flasks of low initial acidity, was probably composed of lactic acid and sorne volatile acids so that the final acid was not strictly comparable to the acid in the flasks of higher initial acid. Whether pure lactic acid, or the resulting mixture of lactic acid and volatile acid, is of higher germicidal value is not clear from these experiments. This introduces a factor of uncertainty which must be reckoned with.

In buttermilk there are many bacteria besides lactic acid bacteria. The presence of these other bacteria may favor the multiplication of pathogenic bacteria by preparing, through their metabolism, food substances from the milk compounds which are more suitable for the nourishment of the pathogenic bacteria. 


\section{CONCLUSIONS}

Some acid-tolerant cells of Bacillus coli may survive the presence of 0.6 percent lactic acid in milk.

B. (iysenteriae, B. typhosus, B. diphtheriae, B. paratyphosus B, and Spirillum cholerae in these experiments were destroyed by the presence of 0.45 percent lactic acid. It is possible that strains of these bacteria exist which are able to resist a greater amount of lactic acid.

Acid-tolerant strains of B. coli, B. dysenteriae, B. typhosus, and B. paratyphosus $B$ may multiply in the presence of quantities of lactic acid which are destructive to the majority of cells. The smaller the initial amount of lactic acid, the more likely is the growth of acid-tolerant strains. Consequently, the slower milk sours, the greater is the danger of pathogenic bacteria surviving.

The growth of the test bacteria is influenced to a marked degree by the amount of acid present. Up to a fairly definite amount of acid there is an increase in numbers, followed by a decrease, which becomes more pronounced as the amount of acid increases. The amount of acid may increase after the number of bacteria has commenced to decrease owing to the liberation of enzymes.

Acids other than lactic acid are frequently present in buttermilk. Buttermilk, therefore, should be looked upon with suspicion, especially if heavily polluted, unless prepared from pasteurized milk. Still the chances of buttermilk becoming a carrier of infection are much smaller than of raw sweet milk.

The presence of saprophytic bacteria in buttermilk may have some influence on pathogenic bacteria. Whether this influence is favorable or otherwise, is difficult to determine by present bacteriological methods. 